\title{
The effect of temperature on the physiological condition and growth performance of freshwater eel elver Anguilla bicolor bicolor (McClelland, 1844)
}

\section{Pengaruh suhu terhadap kondisi fisiologis dan kinerja pertumbuhan elver ikan sidat Anguilla bicolor bicolor (McClelland, 1844)}

\section{Latifa Fekri' ${ }^{12^{*}}$, Ridwan Affandi ${ }^{3}$, Muhammad Fajar Rahardjo ${ }^{3}$, Tatag Budiardi ${ }^{4}$, Charles Parningotan Haratua Simanjuntak ${ }^{3}$, Tezza Fauzan ${ }^{2}$, Indrayani²}

\author{
${ }^{1}$ Study Program of Aquatic Resources Management, Graduate School of Bogor Agricultural University \\ ${ }^{2}$ Department of Aquatic Resources Management, Faculty of Fisheries and Marine Sciences, Halu Oleo University \\ ${ }^{3}$ Department of Aquatic Resources Management, Faculty of Fisheries and Marine Sciences, Bogor Agricultural \\ University \\ ${ }^{4}$ Department of Aquaculture, Faculty of Fisheries and Marine Sciences, Bogor Agricultural University \\ *Corresponding author : latifa_fekri@yahoo.com
}

(Received October 13, 2017; Accepted July 28, 2018)

\begin{abstract}
This study aimed to analyze the effect of water temperature on the physiological condition and growth performance of freshwater eel elver Anguilla bicolor bicolor (McClelland, 1844). This study was conducted in March 2017 at the Physiology Laboratory of Aquatic Animal, Faculty of Fisheries and Marine Sciences, Bogor Agricultural University. The study used a completely randomized design with five different levels of temperature $\left(22^{\circ} \mathrm{C}, 24^{\circ} \mathrm{C}\right.$, $26^{\circ} \mathrm{C}, 28^{\circ} \mathrm{C}$, and $30^{\circ} \mathrm{C}$ ) as treatments with two replications. The size of elver was $2-3 \mathrm{~g}$. The experimental fish were fed with $1 \mathrm{~mm}$ pellet containing $45 \%$ of protein. The feeding level was $7 \%$ of fish biomass and the feeding frequency was two times a day. The results showed that temperatures range from $24-30^{\circ} \mathrm{C}$ could be used for freshwater eel elver rearing and $28-30^{\circ} \mathrm{C}$ were the best temperatures to support survival and growth performance of eel elver. A temperature of $24^{\circ} \mathrm{C}$ was the best temperature that could reduce the metabolism rate and did not cause stress on the elver.
\end{abstract}

Keywords: elver, physiological conditions, growth performance, metabolism, temperature.

\begin{abstract}
ABSTRAK
Penelitian dengan tujuan menganalisis pengaruh suhu terhadap kondisi fisiologis dan kinerja pertumbuhan elver ikan sidat (Anguilla bicolor bicolor McClelland, 1844) telah dilakukan pada bulan Maret 2017 di Laboratorium Fisiologi Hewan Air FPIK IPB. Penelitian menggunakan rancangan acak lengkap dengan lima perlakuan suhu berbeda $\left(22^{\circ} \mathrm{C}, 24^{\circ} \mathrm{C}, 26^{\circ} \mathrm{C}, 28^{\circ} \mathrm{C}\right.$, dan $\left.30^{\circ} \mathrm{C}\right)$ dengan masing-masing dua ulangan. Ukuran benih yang digunakan 2-3 g. Pakan yang diberikan berupa pellet berukuran $1 \mathrm{~mm}$ dengan kadar protein $45 \%$. Jumlah pakan yang diberikan (FR) adalah 7\% dari biomassa ikan dan diberikan dua kali sehari. Hasil penelitian menunjukkan bahwa kisaran suhu $24-30^{\circ} \mathrm{C}$ dapat digunakan dalam pemeliharaan elver ikan sidat dan suhu $28-30^{\circ} \mathrm{C}$ merupakan suhu yang sangat baik untuk mendukung kelangsungan hidup dan pertumbuhan elver ikan sidat. Suhu media $24^{\circ} \mathrm{C}$ adalah suhu terbaik yang dapat menekan laju metabolisme dengan tidak menyebabkan stres pada elver ikan sidat.
\end{abstract}

Kata kunci: elver, kondisi fisiologis, kinerja pertumbuhan, metabolisme, suhu. 


\section{INTRODUCTION}

Freshwater eel Anguilla spp. has a high economical value and one of the export commodities in the fisheries sector. The demand for freshwater eel is very high and it keeps increasing up to 600.000 tons in 2012 (Sugeha, 2013). The prices of freshwater eel ranged between Rp 180.000 to Rp 300.000 per kg. However, the demand for freshwater eel was not in line with the supply. The massive aquaculture activity, especially in East Asia countries (Japan, Taiwan, and China) and in European countries (Italy and Germany) caused massive exploitation of glass eel and elver in the nature (Arai, 2016), therefore the population of glass eel and elver have been decreased drastically (Arai, 2014; ICES, 2011; Solomon \& Ahmed, 2017). The supply of glass eel and elver were decreased up to $80 \%$ (Japan) and 99\% (Europe) from 1984 to 2000 (Dekker et al., 2003). In order to compensate for market demand and availability of stocks in nature, it is necessary to conserve the eel resources in nature, by adding stocks in natural waters through the restocking of eel seeds and avoiding catching seeds from nature.

The important factor that affects the survival and growth of fish instead of their feed is the water quality especially the water temperature. Effendi (2003) stated that water temperature is an important factor in the metabolism process, then it affects the fish survival and growth and fish reproduction. The changes in water temperature in sudden or the occurred of extreme temperature will negatively affect the fish survival, even further cause mass mortality. The decrease of temperature followed by the decrease of enzyme activities in body metabolism could reduce the appetite, therefore as the decreasing of the consumed feed, the growth rate will decrease as well.

Syahailatua (2008) and Nerici et al. (2012) reported that the increasing of water temperature will be followed by the increasing of metabolism degree to fulfill the oxygen need of the organism. This was in line with Van't Hoff rule which stated that the velocity of chemical reactions is increased by two folds or more for each $10^{\circ} \mathrm{C}$ in temperature rise. Deelder (1984) proposed that European eel $A$. anguilla can adapt to the water temperature at a range from 0 to $30^{\circ} \mathrm{C}$. The feeding activity in $A$. anguilla was stopped in less than $10^{\circ} \mathrm{C}$ and more than $38^{\circ} \mathrm{C}$ (Sadler, 1979) and less than $10^{\circ} \mathrm{C}$ and more than $36^{\circ} \mathrm{C}$ in A. japonica (Son et al., 2011).
Tesch (2003) has shown that the optimum of water temperature for rearing of $A$. japonica elver is at a range of $24-28^{\circ} \mathrm{C}$ and $23-26^{\circ} \mathrm{C}$ for $A$. anguilla. The optimum temperature for the rearing of $A$. rostrata glass eel is $18-22^{\circ} \mathrm{C}$ (Blakeslee et al., 2017). According to that, the aim of this study was to analyze the effect of water temperature on the physiological condition and growth performance of freshwater eel elver Anguilla bicolor bicolor (McClelland, 1844).

\section{MATERIALS AND METHODS}

Elver rearing activity was conducted in Physiology of Aquatic Organism Laboratory, Faculty of Fisheries and Marine Sciences, Bogor Agricultural University in March 2017. The blood characteristics including blood glucose, hematocrit, and haemoglobin were analyzed at Physiology Laboratory, Faculty of Veterinary, Bogor Agricultural University. Physical and chemical characteristic of water quality parameters were investigated in Environmental Laboratory, Faculty of Fisheries and Marine Sciences, Bogor Agricultural University. The chemical composition of the fish body including water, protein, fat/lipid, carbohydrate, and ash were analyzed at Laboratory of Research Center for Bioresources and Biotechnology, Bogor Agricultural University.

The study used a completely randomized design with five different temperature treatments $\left(22,24,26,28\right.$, and $\left.30 \pm 1^{\circ} \mathrm{C}\right)$ with two replications. The feeding rate was $7 \%$ of the fish biomass for rearing within a month. The procedure of this study was described below:

\section{The aquarium preparation}

As much as 12 of aquariums with separator and internal recirculation system were used in this study. The separator used to separate the filter and the rearing tank. The water that used for this study was precipitated in the tank for 2-3 days. The aquarium was sizing of $60 \times 40 \times 30 \mathrm{~cm}^{3}$ and the rearing tank was sizing of $50 \times 50 \times 40 \mathrm{~cm}^{3}$. The water was as much as $48 \mathrm{~L}$. The total water changing was done once in every seven days.

\section{The rearing of elver}

The elver eel was prepared as many as 360 eels with a stocking density of 20 eels/aquarium. The elver that used for this study was sizing of 2-3 $g$ from PT. Laju Bayu Semesta, Jl. Raya Cipicung Satu, Cibening, Pamijahan, Bogor, West Java. The powder feed with $46 \%$ of protein content 
was obtained from PT. Laju Banyu Semesta. That powder feed than was solidified into $1 \mathrm{~mm}$ of sinking pellet.

Prior to experiment, the elver was acclimatized for a week. The elver was reared with different temperature treatments for 30 days. The elver was stocked as many as 200 fishes with the stocking density of 20 fishes/aquarium and fed twice a day at 08.00 am (25\% from total feed) and at 04.00 pm (75\% from total feed). The fish fed every day continuously with the feeding level about $7 \%$ of fish biomass. In every morning before feeding, the rearing media was siphoned to remove the residual feed. Every aquarium was equipped with a heater set at the expected temperature and the max-min thermometer to control the temperature. The rearing was conducted in a room with an air conditioner with a temperature of $20^{\circ} \mathrm{C}$.

\section{The observation and measurement procedure}

The parameters that observed in this study were fish mortality and the physiological condition of the fish. The observation was done every day during the rearing period according to the treatments. The parameters that measured in this study were the measurements of body length $(0.1 \mathrm{~mm})$ and body weight (with $0.01 \mathrm{~g}$ of accuracy). The measurement was done four times every seven days during the experiment.

The blood glucose was measured using GODPAP (glucose oxidase phenol 4-aminoantipirin) (Sacks et al., 2011), haematocrit, and haemoglobin (Practice Guidelines, 2015). The blood test was done at the initial and at the end of the experiment. The measurement of chemical composition in elver was done by Weende Experiment Station method (CCP, 2015). The measurement of oxygen consumption rate was performed at the end of the study by closed-loop measurement system (Novita et al., 2011).

\section{The tested parameter}

The tested parameters were physiological condition, growth performance, and water quality. The physiological conditions were body glucose, haematocrit, haemoglobin, and oxygen consumption rate. The growth performance parameters were survival (SR), specific growth rate (SGR), a weight coefficient of variance (CV), feed conversion ratio, and chemical composition of the body. Meanwhile, the water quality parameters were temperature, dissolved oxygen, $\mathrm{pH}$, and ammonia.

The measurement of the growth parameter was done once a week, whereas the physiological condition (stress response) was performed at the initial and the end of the study. The measurement of temperature was conducted every day, while the dissolved oxygen, $\mathrm{pH}$, and ammonia was carried out once in a week, and the measurement of oxygen consumption rate was done at the end of the study. All the parameters were calculated by the following formula below:

$\underset{(\mathrm{mg} / \mathrm{dL})}{\text { Blood glucose }}=\frac{\text { Sample absorbance }}{\text { Standard absorbance }} \times \begin{gathered}\text { glucose standard } \\ \text { content }(\mathrm{mg} / \mathrm{dL})\end{gathered}$

(Sacks et al., 2011)

$\mathrm{Hb}$ content $=$ Absorbance $\times 36.8 \mathrm{~g} / \mathrm{dL} / 100 \mathrm{~mL}$

(Practice Guidelines, 2015)

$$
\text { Hematocrit }=\frac{\text { Packed red cells }}{\text { Total blood volume }} \times 100 \%
$$

(Practice Guidelines, 2015)

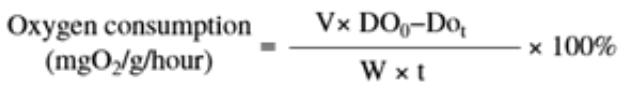

(Liao \& Huang, 1975)

Notes:

$\mathrm{V}=$ Water volume $(\mathrm{L})$

$\mathrm{DO}_{0}=$ Dissolved oxygen concentration in the initiation of the study $(\mathrm{mg} / \mathrm{L})$

$\mathrm{DO}_{\mathrm{t}}=$ Dissolved oxygen concentration in certain time $(\mathrm{mg} / \mathrm{L})$

$\mathrm{w} \quad=$ Fish weight $(\mathrm{g})$

$\mathrm{t}=$ Observation period (hour)

$$
\mathrm{SR}(\%)=\frac{\mathrm{Nt}}{\mathrm{No}} \times 100
$$

(Goddard, 1996)

Notes:

$\mathrm{SR}=$ Survival $(\%)$

$\mathrm{N}_{\mathrm{t}} \quad=$ The total amount of elver at the end of the study

$\mathrm{N}_{0} \quad=$ The total amount of elver in the initiation of the study $\operatorname{SGR}(\% /$ day $)=\left[\sqrt[t]{\frac{W t}{W o}}-1\right] \times 100$

(Huisman, 1987)

Notes:

SGR = Specific growth rate $(\% /$ day $)$

$\mathrm{Wt}=$ Elver biomass at the end of the study (g)

Wo = Elver biomass in the initiation of the study (g)

$\mathrm{t}=\quad=$ Time of rearing (day) 


$$
\mathrm{CV}=\mathrm{S} / \mathrm{Y} \times 100
$$

(Goddard, 1996)

Notes:

$\mathrm{CV}=\mathrm{A}$ weight coefficient of variance $(\%)$

$\mathrm{S}=$ Standard deviation

$\mathrm{Y} \quad=$ Mean

$$
\mathrm{FCR}=\mathrm{F} /(\mathrm{Bt}+\mathrm{Bm})-\mathrm{Bo}
$$

(NRC, 2011)

Notes:

FCR = Feed conversion ratio

$\mathrm{Bt}=$ Total biomass of elver at the end of the study (g)

Bo $=$ Total biomass of elver in the initiation of the study $(\mathrm{g})$

$\mathrm{Bm}=$ Total biomass of dead elver during the study $(\mathrm{g})$

$\mathrm{F} \quad=$ Total feed $(\mathrm{g})$

\section{Data analysis}

The obtained data in this study were analyzed by using Microsoft Excel 2010 and SPSS 21.1 including the homogeneity, normality, analysis of variance (ANOVA) and F test in $95 \%$ of confidence level. This analysis was used to determine the significant differences among treatments toward tested parameter such as survival rate (SR), specific growth rate (SGR), a weight coefficient of variance (CV), and feed conversion (FC). If the data is significantly different, the test will continue to post hoc test in $95 \%$ of confidence level (Steel $\&$ Torrie, 1981) to obtain the difference within treatment. The descriptive analysis was used to explain the effect of the treatments toward glucose value, haemoglobin, haematocrit, oxygen consumption level, the chemical composition of the body, and water quality during elver rearing.

\section{RESULTS AND DISCUSSIONS}

\section{Results}

Physiological condition

The blood characteristic of elver during the rearing is shown in Table 1 . In $24^{\circ} \mathrm{C}$, the data of the glucose level, haemoglobin, and haematocrit were the closest value related to blood characteristic in elver before the treatments.

Oxygen consumption level was increase (0.20-0.41 $\left.\mathrm{mg} \mathrm{O}_{2} / \mathrm{g} / \mathrm{hour}\right)$ along with the increase of temperature $\left(22,24,26,28\right.$ and $\left.30^{\circ} \mathrm{C}\right)$. Blood glucose, haemoglobin, and haematocrit experienced a fluctuation, yet they were still in normal range.

Table 1. Blood characteristic of elver Anguilla bicolor bicolor during the rearing period

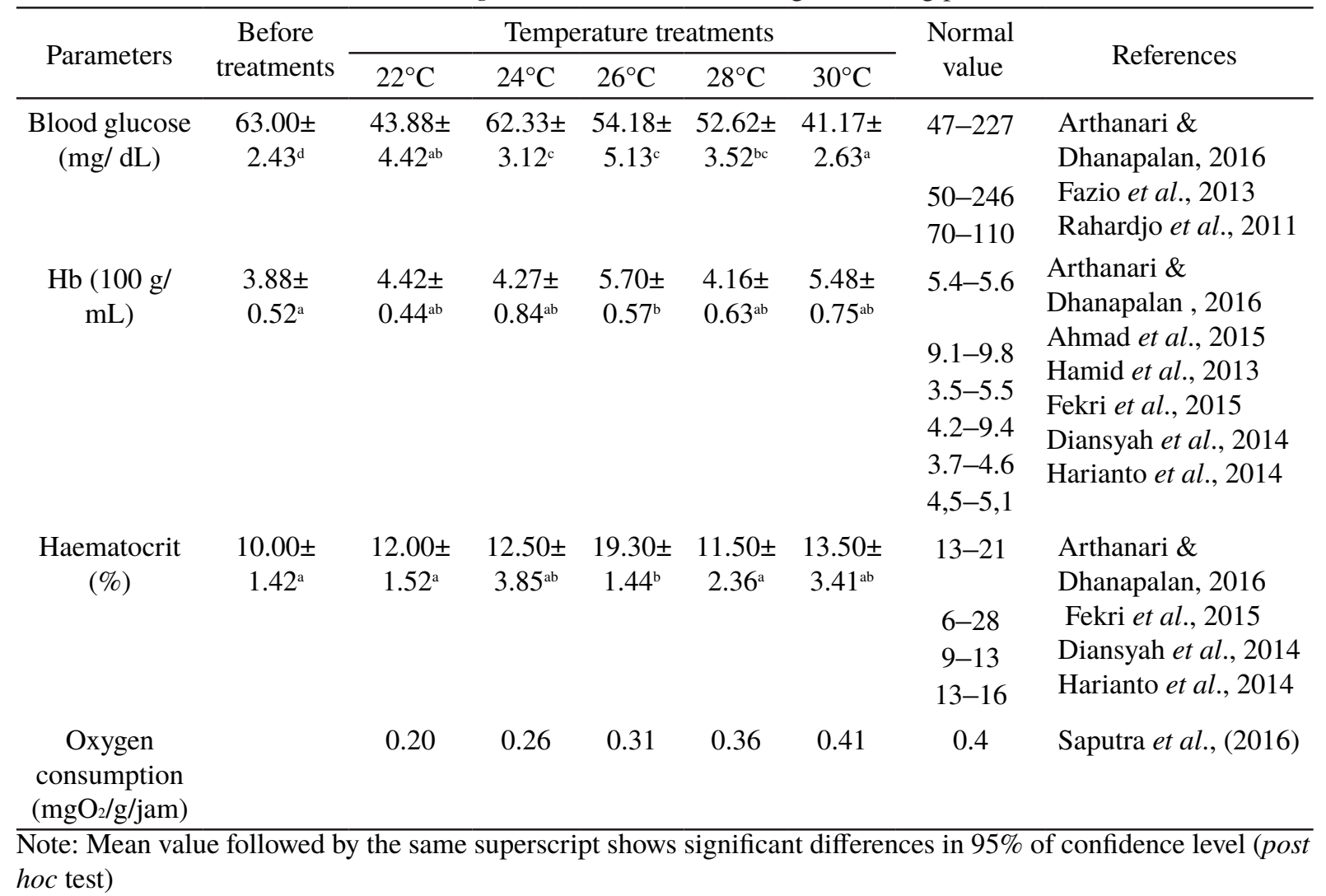




\section{Growth performance}

The growth performance of the elver during the rearing is shown in Table 2. The average of the fish survival was more than $85 \%$ in 24 $30^{\circ} \mathrm{C}$. The increase of temperature was followed by the increase of specific growth rate and a weight coefficient of variance. However, the feed conversion was decreased along with the increasing of rearing media temperature.

\section{The body chemical composition of elver}

The result of the proximate analysis of elver reared in different temperatures $\left(22^{\circ} \mathrm{C}, 24^{\circ} \mathrm{C}\right.$, $26^{\circ} \mathrm{C}, 28^{\circ} \mathrm{C}$, and $30^{\circ} \mathrm{C}$ ) is displayed in Table 3 . The results showed that there was a different body chemical composition of elver in every treatment.

\section{Water quality}

The average value of the physical and chemical of water quality parameters in the elver rearing media with different temperature treatments during the rearing period is presented in Table 4 .
All the average value of physical-chemical parameters during the rearing period was still in the optimum average for elver. Generally, the increasing temperature in the rearing media was followed by the increase of $\mathrm{pH}$ and ammonia.

\section{Discussion}

Eel Anguilla bicolor bicolor has a wide temperature tolerance. Blakeslee et al. (2017) found that the optimum temperature for glass eel A. rostrate rearing was 18 to $22^{\circ} \mathrm{C}$. In this recent study, the elver reared at temperature of $24-30^{\circ} \mathrm{C}$ have showed normal condition, yet the elver started to stress in $22^{\circ} \mathrm{C}$ media temperature. This condition was displayed in the blood characteristic (i.e. glucose, haemoglobin, and haematorit) that started to show differences from that of the normal condition and the oxygen consumption level was low $(0.20 \mathrm{mg} \mathrm{O} / \mathrm{g} /$ hour $)$ and the elver was less active during the rearing in temperature of $22^{\circ} \mathrm{C}$.

Porchas et al. (2009) stated that the blood glucose can be used as the stress indicator of fish

Table 2. The growth performance of the elver during the rearing period

\begin{tabular}{lccccc}
\hline \multicolumn{1}{c}{ Parameter } & $22^{\circ} \mathrm{C}$ & $24^{\circ} \mathrm{C}$ & $26^{\circ} \mathrm{C}$ & $28^{\circ} \mathrm{C}$ & $30^{\circ} \mathrm{C}$ \\
\hline SR $(\%)$ & $85.00 \pm 5.00^{\mathrm{a}}$ & $100.00 \pm 0.00^{\mathrm{b}}$ & $100.00 \pm 0.00^{\mathrm{b}}$ & $100.00 \pm 0.00^{\mathrm{b}}$ & $95.00 \pm 7.07^{\mathrm{b}}$ \\
SGR $(\%)$ & $0.42 \pm 0.00^{\mathrm{a}}$ & $0.52 \pm 0.11^{\mathrm{b}}$ & $0.67 \pm 0.07^{\mathrm{b}}$ & $0.73 \pm 0.02^{\mathrm{b}}$ & $0.70 \pm 0.08^{\mathrm{b}}$ \\
$\mathrm{CV}(\%)$ & $10.46 \pm 0.04^{\mathrm{a}}$ & $12.87 \pm 0.88^{\mathrm{b}}$ & $16.41 \pm 1.09^{\mathrm{c}}$ & $16.16 \pm 1.38^{\mathrm{c}}$ & $16.43 \pm 1.49^{\mathrm{c}}$ \\
FCR & $13.84 \pm 2.70^{\mathrm{a}}$ & $11.12 \pm 2.58^{\mathrm{a}}$ & $13.89 \pm 5.74^{\mathrm{a}}$ & $8.69 \pm 5.03^{\mathrm{a}}$ & $7.75 \pm 3.08^{\mathrm{a}}$ \\
\hline
\end{tabular}

Notes: The value followed by the same superscript shows significant differences in $95 \%$ of confidence level (post hoc test). $\mathrm{SR}=$ survival rate; $\mathrm{SGR}=$ specific growth rate; $\mathrm{CV}$ : a weight coefficient of variance; $\mathrm{FCR}=$ feed conversion ratio.

Table 3. Proximate analysis of elver's body (\% wet weight) during the rearing period

\begin{tabular}{|c|c|c|c|c|c|c|}
\hline \multirow{2}{*}{$\begin{array}{l}\text { The chemical } \\
\text { composition } \\
\text { of the body }\end{array}$} & \multirow{2}{*}{$\begin{array}{l}\text { Before the } \\
\text { treatment }\end{array}$} & \multicolumn{5}{|c|}{ Treatments (temperature) } \\
\hline & & $22^{\circ} \mathrm{C}$ & $24^{\circ} \mathrm{C}$ & $26^{\circ} \mathrm{C}$ & $28^{\circ} \mathrm{C}$ & $30^{\circ} \mathrm{C}$ \\
\hline Water content & $74.41 \pm 0.48^{\mathrm{b}}$ & $78.41 \pm 0.00^{\mathrm{cd}}$ & $77.94 \pm 0.13^{c}$ & $72.91 \pm 0.01^{\mathrm{a}}$ & $75.15 \pm 0.52^{\mathrm{b}}$ & $79.01 \pm 0.05^{d}$ \\
\hline Ash & $3.56 \pm 0.05^{\mathrm{d}}$ & $2.41 \pm 0.07^{\mathrm{a}}$ & $3.38 \pm 0.02^{\mathrm{cd}}$ & $3.63 \pm 0.02^{\mathrm{d}}$ & $2.98 \pm 0.11^{\mathrm{b}}$ & $3.28 \pm 0.19^{c}$ \\
\hline Lipid & $3.82 \pm 0.28^{c}$ & $2.16 \pm 0.18^{\mathrm{a}}$ & $3.21 \pm 0.20^{\mathrm{b}}$ & $5.63 \pm 0.00^{\mathrm{e}}$ & $3.35 \pm 0.35^{\mathrm{c}}$ & $4.54 \pm 0.07^{\mathrm{d}}$ \\
\hline Protein & $16.31 \pm 0.07^{\mathrm{d}}$ & $16.22 \pm 0.07^{\mathrm{d}}$ & $15.20 \pm 0.00^{\mathrm{b}}$ & $17.45 \pm 0.04^{c}$ & $15.63 \pm 0.34^{c}$ & $12.95 \pm 0.01^{\mathrm{a}}$ \\
\hline Crude fiber & $0.32 \pm 0.08^{c}$ & $0.10 \pm 0.01^{\mathrm{ab}}$ & $0.09 \pm 0.09^{\mathrm{ab}}$ & $0.14 \pm 0.00^{\mathrm{b}}$ & $0.15 \pm 0.02^{b}$ & $0.00 \pm 0.00^{\mathrm{a}}$ \\
\hline
\end{tabular}

Note: The value followed by the same superscript shows significant differences in 95\% of confidence level (Post hoc test)

Table 4. The average value of the physical-chemical composition of water during the rearing period

\begin{tabular}{lcccccc}
\hline Parameters & \multicolumn{5}{c}{ Treatments } & $\begin{array}{c}\text { Optimum value } \\
\text { (KKP, 2011) }\end{array}$ \\
\cline { 2 - 6 } & $22^{\circ} \mathrm{C}$ & $24^{\circ} \mathrm{C}$ & $26^{\circ} \mathrm{C}$ & $28^{\circ} \mathrm{C}$ & $30^{\circ} \mathrm{C}$ & \multicolumn{1}{c}{ (K.0 } \\
\hline DO $(\mathrm{mg} / \mathrm{L})$ & $5.70-6.90$ & $5.40-6.70$ & $5.20-6.50$ & $4.40-6.40$ & $4.20-6.20$ & $>4.0-8.0$ \\
$\mathrm{pH}$ & $7.61-7.68$ & $7.12-7.65$ & $7.09-7.81$ & $7.08-7.98$ & $7.05-7.81$ & \\
$\begin{array}{l}\text { Ammonia } \\
(\mathrm{mg} / \mathrm{L})\end{array}$ & $0.003-0.011$ & $0.004-0.015$ & $0.004-0.016$ & $0.006-0.019$ & $0.011-0.026$ & $<0.1$ \\
\hline
\end{tabular}


and the blood glucose concentration can express the health status of fish (Bartoňková et al., 2016). During the elver rearing, the blood glucose was 38.54-65.45 mg/dL. Rahardjo et al. (2011) stated that the normal blood glucose level in fish is 40 $90 \mathrm{mg} / \mathrm{dL}$. This value is relatively close to normal blood glucose level in human, i.e. $70-110 \mathrm{mg} / \mathrm{dL}$. The blood glucose is an important component for many functions in some specific tissues, including the brain, the gill, the erythrocyte, and the gonads (Polakof et al., 2012). Blood glucose in fish body is the main energy source, fuel supply, and essential substrate for cell metabolism, especially for brain cells metabolism. Fish has a mechanism to maintain the blood glucose in several stages (Soengas, 2014) and has the different blood glucose level depend on the fish size and activity (Driedzic et al., 2013).

Yasemi and Nikoo (2010) declared that in stress condition, the glucocorticoid level increases resulted in the increase of blood glucose level. This condition is used to overcome the high needs of the energy during stress. That condition can be fulfilled if only the blood glucose is absorbed into cells immediately. The glucose in cells will be catabolized soon to fulfill the needs of fish body physiology and energy. After the needs are fulfilled, the glycogenesis and lipogenesis process will be started (Polakof et al., 2012; Kamalam et al., 2016).

The haemoglobin $(\mathrm{Hb})$ value of elver after rearing showed $3.36-6.27$ per $100 \mathrm{~g} / \mathrm{mL}$. This result showed an insignificant increase compared with the control and the haemoglobin value after rearing was still within a normal range. This result was in accordance with Zuhrawati (2014) who reported that there was no significant effect of temperature to haemoglobin level in Oreochromis niloticus. $\mathrm{Hb}$ is a protein as a key in transporting the blood oxygen in fish (Rummer \& Brauner, 2015). Radoslav et al. (2013) have shown that the increasing of haemoglobin reflects a stress condition of the fish. Physiologically, the haemoglobin determines the immune system level of fish because its strong connection with the blood. Moreover, the blood ability that used to carry the oxygen is relied on the $\mathrm{Hb}$ level (Rummer \& Brauner, 2011).

Haematocrit or packed cell volume (PVC) is erythrocyte volume in $100 \mathrm{~mL}$ of blood or the comparison within the erythrocyte and the blood plasma in percent (\%). The haematocrit of elver during the rearing was between $8.58-20.74 \%$. The result showed that the haematocrit value was increase compared with the control. Even the blood haematocrit of elver after the rearing was increase but insignificantly different with the haematocrit before the treatments. The haematocrit level after the rearing was still in normal condition. The increasing value of hematocrite level were related with increasing of temperature (Bozorgnia et al., 2011).

The oxygen consumption level is one parameter to understand the fish metabolism rate and the oxygen consumption level is affected by the water temperature (Remen et al., 2015). Table 2 showed that the increasing of water temperature $\left(22-30^{\circ} \mathrm{C}\right)$ was followed by the increasing of oxygen consumption level in elver. When the temperature was increase, the oxygen-utilizing also increase $\left(0.05 \mathrm{mgO}_{2} / \mathrm{g} / \mathrm{hour}\right)$ with the oxygen content reached a range of 5-6 mg/L. The increase of temperature as much as $1^{\circ} \mathrm{C}$ would increase the oxygen consumption level to $10 \%$ (Boyd, 1988). At $30^{\circ} \mathrm{C}$ media temperature, the oxygen consumption level of elver was $0.41 \mathrm{mg}$ $\mathrm{O}_{2} / \mathrm{g} /$ hour. This finding was in line with the study of Saputra et al. (2016) which used elver with a size of $3 \mathrm{~g} / \mathrm{fish}$ at a temperature ranged from 29 to $31^{\circ} \mathrm{C}$. Generally, metabolism rate per weight in smaller fish was higher than that of the bigger one. Therefore, smaller fish required more oxygen than the bigger one. The relationship between the metabolism rate and fish body size was affected by some intrinsic factors (i.e. physiology) and extrinsic factors (i.e. environmental parameter) (Urbina \& Glover, 2013). Scabra et al. (2016) reported that the oxygen consumption level of elver with size of $10 \mathrm{~g} / \mathrm{ind}$ was $0.36 \mathrm{mg} \mathrm{O} / \mathrm{g} /$ hour. KKP (2011) has shown that the eel needs an environment with the oxygen demand of more than $4 \mathrm{mg} / \mathrm{L}$. The lack of oxygen in rearing media can lead to fish stress and mortality (Diaz \& Breitburg, 2009).

Even the result of analysis of variance showed that the temperature treatments $\left(22^{\circ} \mathrm{C}, 24^{\circ} \mathrm{C}\right.$, $26^{\circ} \mathrm{C}, 28^{\circ} \mathrm{C}$, and $30^{\circ} \mathrm{C}$ ) in rearing media were significantly affect the survival rate, but elver was strong enough to deal with the temperature changes. The research showed that survival rate of elver was high. The survival rate of elver was more than $90 \%$ in $24-30^{\circ} \mathrm{C}$ temperatures, while the weak condition of elver with the survival of $80 \%$ was observed in media temperature less than $24^{\circ} \mathrm{C}$. The temperature treatments ranged of 24 to $30^{\circ} \mathrm{C}$ are still tolerated by the elver.

Metabolism rate increases when temperature increases (Schulte, 2015). Thus, the need of energy and consumption rate are raise (O'Connor, 2009; Lemoine et al., 2013). Consequently, the growth 
rate of elver was increase along with the increase of temperature. Our study showed that there was a difference in coefficient of variance of body weight in the different temperature treatments. In the low temperature treatment, elver showed a lower appetite and less movement, therefore the competition in getting feed was low. Accordingly, the low variation of body size was observed in line with the decreasing water temperature, otherwise body weight coefficient of variance was high along with the increasing of the water temperature.

The feed conversion value was fluctuated in accordance with temperature treatments $\left(22^{\circ} \mathrm{C}\right.$, $24^{\circ} \mathrm{C}, 26^{\circ} \mathrm{C}, 28^{\circ} \mathrm{C}$, and $30^{\circ} \mathrm{C}$ ). There was a tendency that FCR value decreases when the temperature increases. The feed conversion ratio (FCR) defines the feed requirement (in $\mathrm{kg}$ ) to obtain $1 \mathrm{~kg}$ of body weight. The feed conversion value is inverse with the feed efficiency value, the lower the FCR value, the higher the feed efficiency is.

Overall, the physico-chemical parameters showed an optimum media condition for elver. The water temperature affects the metabolism rate, feeding activity (Maltez et al., 2016), and the growth of elver (Lefebvre et al., 2011). The increasing temperature will be followed by the increasing of metabolic rate (Claësson et al., 2016). The water temperature affects the oxygen solubility in water. The solubility of oxygen decreases as temperature increases (Kale, 2016). The ammonia toxicity will increase along with the increase of $\mathrm{pH}$ and temperature (Effendi, 2003). The best temperature for the physiological growth of eel as shown in the fish survival was $24-30^{\circ} \mathrm{C}$. The $\mathrm{pH}$ value for elver rearing was ranged from 7.05-7.98. EFSA (2009) stated that the best $\mathrm{pH}$ for eel rearing is neutral with $\mathrm{pH}$ ranged from 6.0-8.0. Bhatnagar and Devi (2013) explained that to increase the productivity, the dissolve oxygen in water should be $5 \mathrm{mg} / \mathrm{L}$. The increasing water temperature will affect the fish physiology (Claësson et al., 2016). The increasing of temperature in the optimum range was followed by the feeding activity and higher needs of oxygen. This caused the oxygen consumption level becomes higher and the ammonia content as excretion outcome increases (Mendonça \& Gamperl, 2010; Healy \& Schulte, 2012; Clark et al., 2013; Gräns et al., 2014; Norin et al., 2014). Ammonia in water can enter the blood stream of the elver through the gills, thereby it causes methemoglobin (brown blood disease), that can kill the fish because the fish experienced hypoxia (the lack of oxygen supply) (Wiesman et al., 2007). During the research, the ammonia content is still tolerable by elver. Yudiarto et al. (2012) found that ammonia concentration between $1.5-2.0 \mathrm{mg} / \mathrm{L}$ still can be tolerated by the elver.

\section{CONCLUSION}

The optimal temperature to support the survival and the growth of elver is between $28-30^{\circ} \mathrm{C}$. The temperature of $24^{\circ} \mathrm{C}$ is the recommended temperature to maintain low metabolism rate without causing stress in elver.

\section{ACKNOWLEDGEMENT}

The authors thank the Ministry of Research, Technology, and Higher Education of the Republic of Indonesia (065/SPRH/LT/DPRM/IV/2017) for funding this research. The authors also thank Hasan Eldin Adimu and Alfi Kusuma Atmaja for helping the authors during this research.

\section{REFERENCES}

Ahmad Y, Andrabi SM, Hussain A, Hussain G, Wani AR, Bannetwala RC, Tharani M. 2015. Haematological studies of fresh water fish, labeo rohita (Hamilton, 1822) exposed to heavy metals. International Journal of Science, Environment, and Technology 4: 1513-1523.

Arai T. 2014. Do we protect freshwater eels or do we drive them to extinction?. Springer Plus 3: 534.

Arai T. 2016. Biology and Ecology of Anguillid Eels. London (NY): CRC Press.

Arthanari M, Dhanapalan S. 2016. Assessment of the haematological and serum biochemical parameters of three commercially important freshwater fishes in river Cauvery Velur, Namakkal district, Tamil Nadu, India. International Journal of Fisheries and Aquatic Studies 4: 155-159.

Bartoňková J, Hyršl P, Vojtek L. 2016. Glucose determination in fish plasma by two different moderate methods. Journal Acta Veterinaria 85: 349-353.

Bhatnagar A, Devi P. 2013. Water quality guidelines for the management of pond fish culture. International Journal of Environmental Sciences 3: 1980-2009.

Blakeslee CJ, Heather SG, Robert MD. 2017. The effects of rearing temperature on American glass eels Anguilla rostrata. Fisheries and Oceanography 2: 555-584. 
Boyd CE. 1988. Water Quality in Warmwater Fish Ponds. Fourth Printing. Alabama (US): Auburn University Agricultural Experiment Station.

Bozorgnia A, Alimohammadi R, Hosseinifard R. 2011. Acute Effects of Different Temperature in the Blood Parameters of Common Carp (Cyprinus carpio). $2^{\text {nd }}$ International Conference on Environmental Science and Technology IPCBEE. Vol.6. IACSIT Press, Singapore.

[CCP] Cereals and Cereal Products. 2015. Manual for analysis of cereal and cereal products. India (ND): Ministry of Health and Family Welfare.

Claësson D, Wang T, Malte H. 2016. Maximal oxygen consumption increases with temperature in the European eel Anguilla anguilla through increased heart rate and arteriovenous extraction. Conservation Physiology 4: 1-8.

Clark TD, Sandblom E, Jutfelt F. 2013. Aerobic scope measurements of fishes in an era of climate change: respirometry, relevance and recommendations. Journal of Experimental Biology 216: 2771-2782.

Deelder CL. 1984. Synopsis of biological data on the eel, Anguilla anguilla (Linnaeus, 1758). FAO Fisheries Synopsis No.80 Revisi 1. Netherland (NLD): Netherlands Institute for fisheries development.

Dekker W, Casselman JM, Cairns DK, Tsukamoto K, Jellyman D, Lickers H. 2003. Québec Declaration of Concern: worldwide decline of eel resources necessitates immediate action. Fisheries 28: 28-30.

Diansyah S, Budiardi T, Sudrajat AO. 2014. Growth performance of 3-g Anguilla bicolor bicolor at different density. Journal Akuakultur Indonesia 13: 46-53.

Diaz RJ, Breitburg DL. 2009. Chapter 1 the hypoxic environment. Fish Physiology 27: $1-23$.

Driedzic WR, Clow KA, Short CE 2013: Glucose uptake and metabolism by red blood cells from fish with different extracellular glucose levels. Journal of Experimental Biology 216: 437-446

Effendi H. 2003. Study of Water Quality: for Resources Management and Aquatic Environments. Yogyakarta (ID): Kanisius.

[EFSA] European Food Safety Authority. 2009. Scientific opinion: animal welfare aspects of husbandry systems for farmed European eel. The European Food Safety Authority Journal
809: 1-17.

Fazio F, Marafioti S, Arfuso F, Piccione G, Faggio C. 2013. Comparative study of the biochemical and haematological parameters of four wild Tyrrhenian fish species. Veterinarni Medicina 11: 576-581.

Fekri L, Affandi R, Budiardi T. 2015. The effect of stunting on the physiological condition of freshwater eel seeds Anguilla bicolor bicolor (McClelland, 1844). Jurnal Iktiologi Indonesia 15: 65-75.

[FAO] Food and Agriculture Organization. 2014. Globefish Research Programme, Eel Anguilla spp.: Production and Trade. Rome (IT): FAO Fishstat Plus.

Goddard S. 1996. Feed Management in Intensive Aquaculture. New York (NY): Chapman and Hall.

Gräns A, Jutfelt F, Sandblom E, Jöhnsson E, Wiklander K, Seth H, Olsson C, Dupont $\mathrm{S}$, Ortega-Martinez O, Einarsdottir I. 2014. Aerobic scope fails to explain the detrimental effects on growth resulting from warming and elevated $\mathrm{CO}_{2}$ in Atlantic halibut. Journal of Experimental Biology 217: 711-717.

Hamid SHA, Ahmed FAM, Mohammed IMA, Ali SIM. 2013. Physical \& chemical characteristics of blood of two fish species (Oreochromis niloticus and Clarias lazera). World's Veterinary Journal 3: 17-20.

Harianto E, Budiardi T, Sudrajat AO. 2014. Growth performance of 7-g Anguilla bicolor bicolor at different density. Jurnal Akuakultur Indonesia 13: 120-131.

Healy TM, SchultePM.2012. Thermal acclimation is not necessary to maintain a wide thermal breadth of aerobic scope in the common killifish Fundulus heteroclitus. Physiological and Biochemical Zoology 85: 107-119.

Huisman EA. 1987. The Principles of Fish Culture Production. Netherland (NLD): Department of Aquaculture, Wageningen University.

[ICES] International Council for the Exploration of the Sea. 2011. Report of the Joint EIFAC/ ICES Working Group on Eels (WGEEL), 3-9 September 2011, Leuven, Belgium (BE): International Council for the Exploration of the Sea.

Kale VS. 2016. Consequence of temperature, $\mathrm{pH}$, turbidity and dissolved oxygen water quality parameters. International Advanced Research Journal in Science, Engineering and Technology 3: 1-5. 
Kamalam BS, Medale F, Panserat S. 2016. Utilization of dietary carbohydrates in farmed fishes: new insights on influencing factors, biological limitations and future strategies. Aquaculture 467: 3-27.

[KKP] Ministry of Fisheries and Marine Affairs. 2011. Guide of eel farming. Jakarta, Indonesia: Pusat Penyuluhan Kelautan dan Perikanan, KKP RI.

Lefebvre MNJ, Bostanian HMA, Thistlewood Y, Mauffette, Racette G. 2011. A laboratory assessment of the toxic attributes of six 'reduced risk insecticides' on Galendromus occidentalis (Acari: Phytoseiidae). Chemosphere 84: 25-30.

Lemoine NP, Drews WA, Burkepile DE, Parker JD. 2013. Increased temperature alters feeding behavior of a generalist herbivore. Oikos 122:1669-1678.

Liao IC, Huang HJ. 1975. Studies on the respiration of economic prawns in Taiwan. I. Oxygen consumption and lethal dissolved oxygen of egg up to young prawn of Panaeus monodon Fabricius. Journal Fisheries Society Taiwan 4: 33-50.

Maltez LC, Stringhetta GR, Pinto DSB, Pellegrin L, Nitz LF Figueiredo MRC, Garcia LO, Barbas LAL. 2016. Temperature and feeding on the modulation of ammonia excretion rate of piaussu Leporinus Macrocephalus. Biota Amazônia 6: 77-83

Mendonça PC, Gamperl AK. 2010. The effects of acute changes in temperature and oxygen availability on cardiac performance in winter flounder Pseudopleuronectes americanus. Comparative Biochemical Physiology A: Molecular and Integrative Physiology 155: 245-252.

[NRC] National Research Council. 2011. Nutrient Requirements of Warmwater Fishes. Washington (DC): National Academy Science.

Nerici C, Silva A, Merino G. 2012. Effect of two temperatures on ammonia excretion rates of Seriolella violacea (palm fish) juveniles under rearing conditions. Aquacultural Engineering 46: 47-52.

Norin T, Malte H, Clark TD. 2014. Aerobic scope does not predict the performance of a tropical eurythermal fish at elevated temperatures. Journal of Experimental Biology 217: 244-251.

Novita Y, Iskandar BH, Murdiyanto B, Wiryawan B, Hariyanto. 2011. Oxygen consumption level of humpback grouper juvenile Cromileptes altivelis with length size of $5-7 \mathrm{~cm}$. Marine Fisheries 2: 1-8.

O'Connor MI, Piehler MF, Leech DM, Anton A, Bruno JF. 2009. Warming and resource availability shift food web structure and metabolism. PLOS Biology 7:1-6.

Patriche T, Patriche N, Bocioc E, Coada MT. 2011. Serum biochemical parameters of farmed carp Cyprinus carpio. Aquaculture, Aquarium, Conservation and Legislation-International Journal of the Bioflux Society 4: 137-140.

Polakof S, Panserat, Soengas J, Moon TW. 2012. Glucose metabolism in fish: a review. Journal of Comparative Physiology 182: 1015-1045.

Porchas MM, Martínez-Córdova LR, RamosEnriquez R. 2009. Cortisol and glucose: reliable indicators of fish stress. Pan-American Journal of Aquatic Sciences 4: 158-178.

Practice Guidelines. 2015. Practice Guidelines for Perioperative Blood Management. Anesthesiology 122: 1-35.

Radoslav D, Aleksandar I, Rajko G, Goran T, Danijela C, Svjetlana L. 2013. Effect of thermal stress of short duration on the red blood cell parameters of Barbus balcanicus Kotlik. African Journal of Biotechnology 12: 2484-2491.

Radu D, Oprea L, Bucur C, Costache M, Oprea D. 2009. Characteristics of haematological parameters for carp culture and koi Cyprinus carpio (Linneaus, 1758) reared in an intensive system. Bulletin UASVM. Journal of Animal Science and Biotechnology 66: 1-2.

Rahardjo MF, Sjafei DS, Affandi R, Sulistiono. 2011. Ikhtiology. Bandung (ID): Lubuk Agung.

Remen M, Nederlof MAJ, Folkedal O, Thorsheim G, Bobadilla AS, Pérez-Sánchez J, Oppedal F, Olsen RE. 2015. Effect of temperature on the metabolism, behaviour and oxygen requirements of Sparus aurata. Aquaculture Environment Interactions 7: 115-123.

Rummer JL, Brauner CJ. 2011. Plasma-accessible carbonic anhydrase at the tissue of a teleost fish may greatly enhance oxygen delivery: in vitro evidence in rainbow trout, Oncorhynchus mykiss. Journal of Experimental Biology 214: 2319-2328.

Rummer JL, Brauner CJ. 2015. Root effect haemoglobins in fish may greatly enhance general oxygen delivery relative to other vertebrates. Journal Plos One 5: 1-17.

Sacks DB, Arnold M, Bakris GL, Bruns DE, Horvath AR, Kirkman MS, Lernmark A, 
Metzger BE, Nathan DM. 2011. Guidelines and recommendations for laboratory analysis in the diagnosis and management of diabetes mellitus. Clinical Chemistry 57: 1-47.

Sadler K. 1979. Effect of temperature on the growth and survival of the European eel, Anguilla anguilla L. Journal of Fish Biology 15: 499-507.

Saputra A, Budiardi T, Supriyono E. 2016. Production performance of eel Anguilla bicolor bicolor with the addition of calsium carbonat. Jurnal Akuakultur Indonesia 15: $56-62$.

Scabra AR, Budiardi T, Djokosetiyanto D. 2016. Production performance of Anguilla bicolor bicolor with the addition of $\mathrm{CaCO}_{3}$ into culture media. Journal Aquaculture Indonesia 15: $1-7$.

Schulte PM. 2015. The effects of temperature on aerobic metabolism: towards a mechanistic understanding of the responses of ectotherms to a changing environment. The Journal of Experimental Biology. 218: 1856-1866.

Soengas JL. 2014. Contribution of glucose-and fatty acid sensing systems to the regulation of food intake in fish. A review. General and Comparative Endocrinology 205: 36-48.

Solomon OO, Ahmed OO. 2017. European eel: ecology, threats and conservation status. Journal of Scientific Research and Reports 10: $1-13$.

Son MH, Kim KW, Kim KD and Kim SK. 2011. State of aquaculture management for optimal rearing of eel, Anguilla japonica. Korean Journal of Fisheries and Aquatic Science 44: 359-365.

Steel GD, Torrie JH. 1981. Principles and procedures of statistics. Translation: Bambang Sumantri. Jakarta (ID): PT. Gramedia Pustaka Utama.

Sugeha HY. 2013. Biodiversity of Indonesian Anguilla eels [International Workshop of
Anguilla Eels]. Jakarat (ID): Research Center for Oceanography, Indonesia Institute of Science.

Syahailatua A. 2008. Effect of climate change to fisheries. Oseana 33: 25-32.

Tesch FW. 2003. The Eel; Biology and Management of Anguillid Eels, 3rd ed. Oxford, (UK): Blackwell Publishing.

Urbina MA, Glover CN. 2013. Relationship between fish size and metabolic rate in the oxyconforming inanga Galaxias maculatus reveals size-dependent strategies to withstand hypoxia. Physiological and Biochemical Zoology 86: 740-749.

Well RMG, Baldwin J, Seymour RS, Christian K, Britain T. 2005. Blood cell function and haematology in two tropical freshwater fishes from Australia. Comparative Biochemistry and Physiology 141: 87-93.

Well RMG. 2009. Blood-gas transport and hemoglobin function: adaptations for functional and environmental hypoxia. Fish physiology 27: 255-299.

Wiesman U, Choi IS, Dombrowski M. 2007. Fundamental of Biological Wastewater Treatment. Germany: WILEY-VCH Verlag GmbH\&Co.

Yasemi M, Nikoo M. 2010. The impact of captivity on fertilization, cortisol and glucose levels in plasma in kutum broodstock. Iranian Journal of Fisheries Sciences 9: 478-484.

Yudiarto S, Arief M, Agustono. 2012. Effect of addition of different attractants in pasta feed to protein retention, fat and energy of elver eels seed Anguilla bicolor. Scientific Journal of Fisheries and Marine 4: 135-140.

Zuhrawati NA. 2014. Effect of temperature increase on hemoglobin and hematocrit value of Tilapia fish (Oreochromis niloticus). Journal Medica of Veterine 8: 84-86. 